\title{
OTHER THEMES \\ The Basic Education in Sweden and Brazil: some similarities and differences
}

\author{
Carlos da Fonseca Brandão' \\ 'Universidade Estadual Paulista (UNESP), São Paulo/SP - Brazil
}

\begin{abstract}
The Basic Education in Sweden and Brazil: some similarities and differences. This article proposes to analyze the basic education system of Sweden and to compare it with the basic education system of Brazil. We consider it relevant to compare the two systems of Basic Education, despite the significant differences between the two countries (culture, history, size, population density, etc.), since the quality indicators of basic education in Sweden are considerably better than Brazilians. Our objective is to show the main similarities and differences between the two systems of Basic Education. In order to do so, we first described the structure and functioning of the Swedish Basic Education system, little known to us Brazilians, so that, in our conclusions, we highlight the main similarities and differences between them. The methodology adopted was qualitative exploratory research, with a review of the literature of authors who work with comparative studies in the educational area.

Keywords: Basic Education. Swedish Educational System. Comparative Education.
\end{abstract}

RESUMO - A Educação Básica na Suécia e no Brasil: algumas semelhanças e diferenças. Este artigo pretende analisar o sistema de educação básica da Suécia e compará-lo ao do Brasil. Consideramos relevante comparar os dois sistemas, apesar das significativas diferenças entre os dois países (cultura, história, tamanho, densidade populacional, etc), pois os indicadores de qualidade da educação básica sueca são consideravelmente melhores do que os brasileiros. Para tanto, em um primeiro momento, descrevemos como se estrutura e como funciona o sistema de educação básica sueco, pouco conhecido de nós brasileiros, para, em nossas conclusões, destacarmos as principais semelhanças e diferenças entre os dois sistemas. A metodologia adotada foi a pesquisa exploratória qualitativa, com uma revisão da literatura de autores que trabalham com estudos comparativos na área educacional.

Palavras-chave: Educação Básica. Sistema Educacional Sueco. Educação Comparada.

Educação \& Realidade, Porto Alegre, v. 44, n. 1, e81083, 2019.

http://dx.doi.org/10.1590/2175-623681083 
The Basic Education in Sweden and Brazil

\section{Introduction}

This article analyses the structure and the operation process of the Basic Education system in a developed country, in this case, the Swedish educational system, and later compare it to the structure and the operation of the Brazilian Basic Education, more specifically at the level of Elementary Education. Our main objective is to highlight the main similarities and differences between the Basic Education system of Sweden and that of Brazil. How, in general terms, the Swedish educational reality is little known to us Brazilians, a considerable part of this article was devoted to describing it ${ }^{1}$.

We also consider it relevant to compare the two systems of Basic Education, despite the significant differences between the two countries (culture, history, size, population density, life style, etc.), because the quality indicators of basic education in Sweden are considerably better than Brazilians. Our main theoretical and methodological reference is the comparative studies in educational area, with the literature review $^{2}$. In the conclusion, we will show the main similarities and differences between them ${ }^{3}$.

According to Carvalho, studies in the field of Comparative Education are relatively recent, since the "[...] first works considered of scientific character in this field date from the end of century XIX". According to this author, this "[...] late emergence is explained by the fact that its object is the national systems of education, which came to be created in the nineteenth century."4 Thus, the "process of creation of education systems throughout the nineteenth century was, therefore, the basis of the construction of comparative studies in education" (Carvalho, 2014, p. 130)

For Franco, the importance of conducting comparative studies, among other reasons, lies in "knowing others [...] and in that act, deepening the knowledge of oneself and the other", thus, the

The principle of comparison is the question of the other, the recognition of the other and of self by the other. Comparison is a process of perceiving differences and similarities and of assuming values in this relationship of mutual recognition. It is about understanding the other from the self and, by exclusion, from perceiving the difference (Franco, 1992, p. 14).

However, for Franco, comparing does not mean homogenizing, on the contrary, the comparison, with the respective perception of differences, must take place "[...] under the postulate of equal rights to survival, politics, culture"6. Thus, if we compare societies in which such rights are significantly disparate, we will necessarily encounter equally disparate realities, thus undoing the "pasty homogeneity of abstract equality" (Franco, 1992, p. 33) ${ }^{7}$. In the same sense, Kandel was one of the first authors in the field of Comparative Education in the first decades of the 20th century to emphasize that, in order to understand national educational systems, "[...] political, social and cultural forces must be taken into account", as well as the "national character" that determine their particularities (Kandel, 1933, p. 27). 
Taking into account, on the one hand, local (national) realities and, on the other hand, the incisive process of globalization, especially economic and cultural, present at the beginning of the 21st century, what would be the present challenges for the students who use the methodology of comparative education to conduct research in the educational field? The answers to this question, although punctually different, converge in the same direction. According to Carvalho, the "[...] process of reorganization in educational systems in different countries, according to patterns without frontiers" is what gives "[...] a new importance to Comparative Education and puts its researchers in the face of new challenges" (Carvalho, 2014, p. 135) .

According to Lima and Afonso, the current context requires the researcher to be able to "[...] identify recurrent topics, similarities in rhetoric produced and proposed solutions, but also significant dissimilarities and particular national traits" and they should avoid the "[...] decontextualized reproduction of analyses and criticisms produced in other contexts", as well as the excessive valuation of local factors. These authors suggest that the theoretical-methodological position of the researcher in Comparative Education should be to identify what is common or identical and simultaneously what is unique and specific (Lima; Afonso, 2002) ${ }^{10}$.

In the specific case of our research, which aims to compare the education systems of a European country (Sweden) and a country in South America (Brazil), which means that we will be comparing the education system of a country considered developed, belonging to the so-called First World and a country considered in development, belonging to the so-called Third World, we consider it necessary to highlight some considerations of Franco for the analysis of analogous situations. For this author,

[...] the question of comparative studies and education of dependent countries, compared to the educational systems of the advanced countries, is fundamentally the analysis of the product of an asymmetric situation of domination/dependence, which qualifies for the unequal and combined development of the countries under the strategy of expanding the accumulation of transnational capital (Franco, 1992, p. 33).

Thus, following the author's reasoning, the first point that deserves our full attention is to see (and understand) the "[...] dramatic distance that separates us and separates our countries and our education from the economically developed countries". The second point is to understand that, in a sense, "[...] both are incomparable systems, insofar as they are the fruits of particular historical processes, of singular trajectories, notwithstanding their similarities" (Franco, 1992, p. 34-35).

In order to solve the question posed above, the question of comparing that which in a certain sense (according to Franco) is incomparable, we return to support in Carvalho, which proposes that research in Comparative Education should have as a theoretical and methodological presupposition the dialectical perspective. According to this author, through the use of this perspective

Educação \& Realidade, Porto Alegre, v. 44, n. 1, e81083, 2019. 
The Basic Education in Sweden and Brazil

[...] it is possible to clarify what generates the process of globalization itself, which articulates or dissolves the local, the national and the global. It favors the elucidation of dynamic mediations and interactions, showing the place that local factors occupy in the most general movement of society, and at the same time the universal in the particular, as well as the contradictory forces acting in this relational movement (Carvalho, 2014, p. 139).

Discussing the relationship between development and comparative education, Makuwira and Ninnes argue that one of the main issues is the role of comparative education for the development of local communities. In this sense, we have to be firmly critical of the proposals of top-down multilateral organizations, which usually propose the same educational solutions to the most different contexts. It is also important to emphasize the importance of our role as educators, of critical mass trainers of opposition to unbridled globalization, globalization that aims to replace the local agenda (the resolution of local problems) by a global and transnational agenda, which disregards the local realities (Makuwira; Ninnes, 2004). In fact, like Halls said, we study foreign education, with the comparative studies in education methods, because, among other things, we want to improve our own education system (Halls, 1990).

\section{The structure and organization of Swedish Basic Education}

The structure of the Basic Education system in Sweden is broadly similar to the structure of the Brazilian Basic Education system, with some differences. The entire Swedish educational system is governed

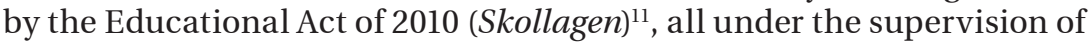
the Swedish National Agency for Education (Skolverket) ${ }^{12}$.

Despite the existence of this national regulatory agency for education (Skolverket), education management is decentralized, being the responsibility of the municipalities. Thus, it is the municipalities that are responsible for offering Basic Education, beginning with Early Childhood Education. For a Swedish child, from a little over one year of age, preschool places are already available at the municipal school of Early Childhood Education ( förskola), which is not compulsory and can be both public and private, also called independent schools ${ }^{13}$. Even when private (independent schools), the Swedish preschool is fully financially accessible to all Swedish families, since the monthly amount charged is based on family income. The municipality is responsible for supervising the public and independent preschools, which must comply with the same rules as municipal preschools ${ }^{14}$.

The main idea behind the so-called Swedish pre-school (förskola) is that at this stage of the child's life the child must have a set of pedagogic activities that stimulate his/her creativity through play activities that help him/her explore the environment and him/herself, in groups and with adults.

The Swedish preschool concept understands that it is the preschool that will lay the foundation for all the learning the child will have through- 
out his or her life. Thus the child should be encouraged, in every way, to learn. In this sense, preschool must be different from the school form, that is, all situations experienced are potentially teaching and learning situations for the child of that age, therefore, the preschool should be, above all, child-friendly ${ }^{15}$.

Under these conditions, the whole school is responsible for the development and learning process of the child, not just the teacher therefore, the planning of the activities to be carried out by the children must necessarily be elaborated by the school staff. For this to be effective, it is fundamental that the school environment is a safe environment (in the pedagogical and physical sense), both for the children themselves and for their parents.

When a Swedish child reaches the age of 6 , he/she attends the preschool class (förskoleklass) which aims to facilitate a transition for the child from preschool to the first year of elementary school. To that end, pre-school classes have the freedom to choose their didactic-pedagogical method, alternating activities that were already present in the preschool with some activities that will be present in basic education. The main purpose of the preschool classes is to stimulate the development of learning. The municipalities are responsible for the provision of pre-school classes, which are totally free, including for families with children with special needs.

In Sweden, compulsory schooling begins after preschool and comprises nine years; it is divided into three cycles, lasting three years each. This set of three cycles is the Swedish Basic Education, which is compulsory and free, called grundskola. The first cycle, which comprises the first three years, is called lågstadiet. The second cycle is called mellanstadiet and the third cycle is the högstadiet. The obligation to attend Basic Education extends to every child resident in Sweden ${ }^{16}$.

The Swedish Basic Education System has four different types of school. Grundskola is the regular school, specialskola is the special school for students with special needs, sameskola is the school for Sami children and grundsärskola is the school for children with learning difficulties. Unlike grundskola, specialskola lasts for 10 years and sameskola lasts for 6 years, but at the end of it, sameskola students continue their studies (the third cycle, högstadiet) in a regular school (grundskola) ${ }^{17}$.

The next level of the Swedish education organization is the threeyear non-compulsory secondary school (gymnasiet). Although not compulsory, secondary education (gymnasiet) in Sweden is attended by the vast majority of young Swedes called Upper Secondary Education. Swedish secondary education (gymnasieskola), as well as other levels of education, is free. It consists of national programs, introductory programs and programs that differ from the national program structure ${ }^{18}$.

To enter the gymnasiet (Upper Secondary School) the student, based on the grades obtained in the ninth year of Basic Education (last year of the third cycle, högstadiet), enrolls in the school of his preference. This secondary education is offered in two types of school, the regular 
The Basic Education in Sweden and Brazil

schools (gymnasieskola) and the schools for students with learning difficulties (gymnasiesärskola), both free and non-compulsory.

The main functions of the Swedish secondary education (gymnasiet) are to provide the Swedish youth with a knowledge base to assist them in their professional choice (higher education) and to supplement the knowledge acquired in compulsory Basic Education (grundskola), contributing to their personal development and in their active participation in social life (construction of citizenship). Swedish upper secondary education is intended for young people between the ages of 16 and 20 . After the age of 20, the young person is considered an adult and can attend adult secondary education or special education for adults with learning difficulties (särvux).

The Swedish secondary education (gymnasieskola) is composed of three types of courses (or programs): national programs, introductory programs and programs which differ from the national program structure, such as programs for the development of sports activities. Students who, at the end of the ninth year of compulsory basic education, have been approved in the Swedish Language, English and Mathematics and have passed other 9 subjects, have the right to join a College preparatory program. The national programs cover 18 different study programs, 12 of which are directed to vocational training and 6 of these national programs are designed to prepare students for higher education. These national programs consist of disciplines, orientations, specializations and a kind of completion project (diploma project).

Beyond the so-called National Programs, the Swedish educational system offers further 5 other programs, called introductory programs for students who are not eligible for a national program, for pupils who, at the end of compulsory education (more specifically in grundskola's ninth year), although approved, did not score high enough to join a National Program. None of these five introductory programs provides a high school diploma because its purpose is to prepare the student to join a National Program or prepare the student to enter the job market, albeit with a more basic preparation, below level professionalism of the national programs for vocational training ${ }^{19}$.

A second type of upper secondary education in Sweden is the Upper Secondary School for Individuals with Learning Disabilities (USSILD), which is not compulsory, like all Swedish secondary education, with a more flexible curriculum, for young people who have developmental disorders or even brain lesions. The USSILD can be a national program, individual programs or programs that differ from the national structure, depending on the specificities and needs of the students. There are 9 national secondary education programs for individuals with learning disabilities and each of these programs lasts for 4 years. The focus of these national programs is essentially vocational, in the sense of preparation for work, within the conditions and limitations of students with learning disabilities, but can also be taught only as secondary school learning. 
All Swedish national secondary education programs work with subjects such as English, history, arts, physical education and health, mathematics, science, civics, Swedish literature, Swedish as a second language and religion. Individual programs, in turn, are programs for students who are unable to undertake a national program. This type of program also lasts for 4 years and is structured in the format of thematic areas, which are: nature and environment; Society and individual; Home and consumer science; Language and communication; Physical education and health; and artistic activities.

As we have already said, once you have reached the age of 20, if you have not attended Upper Secondary School but now wish to do so, your option is to attend adult education (vuxenutbildning). Adult education in Sweden is divided into three types: regular adult education (kommunalvuxenutbildning); special education for adults with learning difficulties (särskid utbildning för vuxna); and the Swedish school for immigrants (Svenska för invandrare).

As in the other school levels we have already described, the provision of adult education in Sweden is also the responsibility of municipalities. Although the choice of adult education is voluntary for adults themselves, municipalities are obliged to offer adult education programs for both, compulsory basic education and Upper Secondary School. At the Upper Secondary School, the methodology of the teaching-learning process should prioritize adults who have received less education up to that point.

At the end of Swedish adult education, at the compulsory level, offered in the format of courses and each course with a specific program, the adult student can go to Upper Secondary School for adults or to stop studying. If he/she continues to study, at the end of Upper Secondary School he/she can earn a professional degree or, if he/she has achieved 2400 credits in Upper Secondary School, to follow to higher education.

Adult special education, in turn, is a specific form of adult education with learning disabilities (USSILD), offered at both the compulsory basic education level and the Upper Secondary School level. Content provided in special adult education shall be equivalent to that provided at the regular school for individual with learning disabilities at both levels (Elementary School and Upper Secondary School).

Even with adult education, the Swedish educational system offers adult immigrants over the age of 16 the opportunity to learn Swedish in order to adapt to and actively participate in Swedish society more quickly. In the practice of daily life, this means that the immigrant is able to communicate, orally and in writing, starting from what he/she already has in terms of communication in Swedish, most of the time, practically nothing.

Finally, in the context of the Swedish educational structure, there are Folk High Schools (folkhögskola). These schools are aimed at young people over the age of 18 and their main distinguishing characteristic is that they have an extremely flexible curricular organization and a pedagogical

Educação \& Realidade, Porto Alegre, v. 44, n. 1, e81083, 2019. 
The Basic Education in Sweden and Brazil

proposal based on the idea of popular education ${ }^{20}$. All Folk High Schools (folkhögskola) offer the general course (Allmän kurs or Behörighetsgivande kurs) whose aim is to grant compulsory primary schooling (equivalent to grundskola or Elementary School) or secondary education (equivalent to gymnasiet or Upper Secondary School).

In addition to this course, there are specialized courses (Profilkurser) and vocational training courses (Yrkesutbildningar), which either prepare young people for entry into higher education or provide professional qualifications for the labor market. These schools are maintained by municipalities or Non-Governmental Organizations, the classes (and courses) can be presential (even in boarding school) or distance, and have full freedom of curricular organization and pedagogical proposal.

Thus, the young Swede (or non-Swedish resident) who finishes Upper Secondary School, in addition to the option of attending a Folk High School (folkhögskola), if over 18, also has other options to continue his/her studies. These options are to study in a school of complementary education (kompletterande utbildning), in a higher vocational education (yrkeshögskolan), in colleges (högskola) or in the universities (universitet).

Complementary education (kompletterande utbildning) is composed of independent educational programs for young people and adults, supported by public power, art, dance, music, theater, fashion, media, aviation, health, etc. Although there are more than 300 courses of this type, most of them concentrate on the artistic area, and many of them are a kind of preparatory faculty for the deepening of the studies in the colleges, in the same field of knowledge.

There are also complementary education courses of a professional nature, such as flight instructor, hairdresser, masseur, etc., so that the young person, once he/she completes the courses, can enter the labor market. These courses are post-secondary courses, that is, they are higher education courses (vocational or not) but are not undergraduate courses. Like Folk High Schools (folkhögskola), complementary education courses (kompletterande utbildning) also allow the student to subsequently enter a college (högskola) or a university (universitet).

Another option that a young Swede has when finishing the Upper Secondary School is the higher vocational education (yrkeshögskolan). They are also postsecondary education courses more directly targeted to the labor market and their labor needs, so the types of courses offered may vary from time to time. They are divided into two types of courses: Higher Vocational Training (HVEC) and Vocationally Qualified (KY) courses. The main feature of these courses is the experience in the workplace, which covers a third of the total course.

Having completed the Upper Secondary School and/or a Folk High Schools (folkhögskola), and/or complementary education (kompletterande utbildning), and/or a higher vocational education ( yrkeshögskolan), the young Swede can enroll in colleges (högskola) or univer- 
sities (universitet), always respecting the rules of eligibility. There are colleges (högskola) and universities (universitet) in more than 20 cities throughout Sweden, with the most different types and programs.

Admission to colleges or universities can be in two ways. The student can enroll in the system called antagning, which will classify candidates based on the grades obtained in Upper Secondary School (or equivalents). The second path to entry into Swedish higher education is for the student to do a standardized test, applied nationally twice a year, called högskoleprovet, which is an additional selection factor for courses in which the quantity of candidates is higher than the number of vacancies available.

\section{The Swedish Educational System and the Brazilian Educational System: some similarities and differences}

In terms of formal organization, the Swedish educational system is organized in a similar way to the Brazilian educational system. Also as in Brazil, the Swedish Basic Education is comprised of Early Childhood Education (förskola), the Elementary School (grundskola) and the Upper Secondary School (gymnasiet), while Higher Education comprises post-secondary (folkhögskola, kompletterand utbildning or yrkeshögskolan), colleges (högskola) and universities (universitet).

In addition to these levels of education, the Swedish educational system, also offers special education to students with special difficulties (specialskola, grundsärskola, gymnasiesärskola or särskid utbildning för vuxna), regular adult education (kommunalvuxenutbildning), virtual learning education, education for a specific ethnic group (sameskola for Sami children and basic education for adult immigrants, understood as teaching modalities).

In terms of educational legislation, like the Brazilian educational system, the Swedish educational system is also governed by a specific national education law, the Educational Act of 2010 (Skollagen). In the context of the organization of the Swedish education system, there is a specific agency responsible for regulating and supervising education (Skolverket), as well as another agency responsible for supervising the quality of education in Swedish schools, called Swedish Schools Inspectorate (Skolinspektionen). This agency is also responsible for receiving, evaluating and resolving all claims about the school problems, and, in this case, relatively different from Brazil ${ }^{21}$.

Analyzing each of the levels and modalities of teaching we can find other similarities and other differences. Beginning with Early Childhood Education, we have that, in Brazil, Early Childhood Education is divided into kindergartens (for children from 0 to 3 years old) and preschool (for children of 4 and 5 years). In Sweden, this division does not exist. In fact, there are no day care centers, but only Early Childhood Education (förskola).

This is basically possible because Swedish families can benefit from the parental leave, which means that, on the one hand, parents 
The Basic Education in Sweden and Brazil

can, alternately, be fully present with their newborn children until they reach at least the age of 1 year and 4 months. On the other hand, at this age (or later) and with a conception of integral child education, strongly anchored in the idea of playing, discovering and exploring (himself and the world around him), Early Childhood Education (förskola) replaces, in practice, the Brazilian daycare ${ }^{22}$.

Another significant difference at the level of Early Childhood Education between the Swedish educational system and the Brazilian educational system is the existence of the pre-school class (förskoleklass). When a Swedish child is 6 years old, she goes to the pre-school class (förskoleklass), whose goal is to make the transition between the Early Childhood Education (förskola) and the Elementary School (grundskola), it is the school year in which the child's activities will be on a school with the focus on the traditional teaching of school subjects.

The Swedish pre-school class (förskoleklass) does not exist in the Brazilian educational system, quite the contrary, when, in 2006, we increased the Brazilian Elementary School from 8 to 9 years in length, we only anticipated the formal beginning of the literacy process for Brazilian children, since, in practice, in many Brazilian pre-schools (specifically the privates pre-schools) children were already literate. Thus, presently, although the Brazilian pre-schools also focus on the idea that the playful character should prevail (play, run, play, etc.) at the beginning of the child's "school life", these schools are for four-to-five-years old children. At the age of 6 , the Brazilian children begin Elementary School.

Before we talk about Elementary School, we need to address the issue of mandatory education. In Brazil, as of 2017, mandatory education is now ages 4 to 17 years. This change was mainly due to the fact that in Brazil there are many children in the age group of 4 to 5 years who did not attend pre-school and many surveys have indicated that the child who attends preschool benefits more from school life and is more likely to remain in school and thus able to successfully complete his/her schooling. On the other hand, it was also necessary to increase the compulsory education to the Upper Secondary School because also many young Brazilians of this age group (15 to 17 years old) discontinued their education ${ }^{23}$.

The Brazilian Elementary School is the level of education formally more similar to its Swedish equivalent (the Swedish Elementary School), since both have duration of 9 years and, in general, have the same pedagogical and educational objectives. In our analysis we highlight three differences, two that we consider more formal and a third difference of conceptual character. The first of the two formal differences is the starting age of Elementary School (in Brazil at 6 years of age and in Sweden at 7 years of age). However, the existence of the Swedish pre-school class (förskoleklass) makes the two systems of education (Brazilian and Swedish) similar at this point (age of initiation of the "school process").

The second of the formal differences refers to the issue of learning cycles. While in Sweden the Elementary School is divided into three 
cycles of three years each, in Brazil, the determination of the existence of cycles and, if any, their durations, are the responsibility of the municipalities or the States, since, in Brazil, the responsibility for the Elementary School offer is, primarily, of the municipalities, but can also be done by the States ${ }^{24}$.

The third difference, of more conceptual character, is the separation, in Sweden, between the regular Elementary School (grundskola) and the special school for people with special needs (specialskola) with 10 years of duration. In Brazil, the so-called Inclusive Education has been adopted as a State policy, which seeks to include children with special needs in the so-called regular classes, making, at this point and in a way, the Brazilian educational policy adopted to care for people with disabilities is different of the Swedish educational policy for the care of this specific public ${ }^{25}$.

The difference we are referring to is the fact that the proposal of Inclusive Education in Brazil as State policy is predominant throughout the Brazilian educational system, at the same time that the proposals of special classes for students with special needs are seen, currently, as segregationist and discriminatory proposals. In Sweden, both conceptions (Inclusive Education and special classes for students with special needs and learning difficulties) are equally understood (and valued) as part of the same educational policy.

The sameskola, for Sami Swedish children, is also another difference between the Brazilian and Swedish system of education, of course. But, although the Sami children must do the third cycle, (högstadiet) in the regular school (grundskola), this difference, in the formal aspect, is, in our opinion, minimized. On the other hand, the sameskola, can be compared with keeping the due proportions, the Brazilian Indigenous Education $^{26}$.

The next level of education that we will point out the similarities and differences between the Swedish and Brazilian educational system is the High School, called, in Sweden, Upper Secondary School (gymnasiet). Formally, both have a duration of three years, and in Sweden it is not mandatory, but the vast majority of young Swedes attend it, and in Brazil it became mandatory as from 2017, because more than $50 \%$ of young Brazilians 15 to 17 years old do not attend any schools ${ }^{27}$.

A first significant difference between the Swedish and Brazilian educational system, specifically with regard to Secondary Education, or Upper Secondary School (gymnasiet), is actually due to student achievement in the ninth year of Basic Education (last year of the third cycle, högstadiet), defining whether he will attend the national program, introductory programs or other program. In a certain way, this definition will also determine, to a large extent, its future educational path, that is, whether it is eligible for the Swedish colleges (högskola) or Swedish universities (universitet).

In Brazil, in addition to secondary education, it is compulsory, its structure and organization are practically the same in the whole coun- 
The Basic Education in Sweden and Brazil

try, and can be either preparatory, vocational or both ${ }^{28}$. In contrast to what happens in Sweden, the performance of the Brazilian student in the final year of Elementary School does not determine the type of High School that the student will attend, that, to continue to Higher Education, the Brazilian student must have successfully completed propaedeutic Secondary Education or both (propaedeutic and vocational secondary education $)^{29}$.

Although it is not a level of education but a modality of education, the issue of Youth and Adult Education is substantially different in the Swedish and Brazilian educational realities. In Brazil, when we talk about Youth and Adult Education, we are referring to young people and adults (above 15 years) who are not literate or insufficiently literate. Thus, the Education of Youths and Adults in Brazil has the objective of solving these problems. For this purpose, courses are offered in a shorter time, and at the end (and if successful) the young person (or adult) receives the certificate of completion of Elementary School or High School. Thus, as in other developed countries, in Sweden, when it comes to youth and adult education, it is assumed that young people have successfully completed at least compulsory schooling, the Elementary School, are at least 20 years of age, and want to do High School (vuxenutbildning), or the regular adult education (kommunalvuxenutbildning).

In Sweden, Youth and Adult Education, in most situations, is a way of complementing basic and compulsory education already received by Swedish youth and adults, it has as a background the idea that the adult can always learn and not exclusively in Higher Education, in lines, the idea of lifelong learning ${ }^{30}$.

In Sweden, also, one area of Adult Education is called Liberal Adult Education. The concept behind this idea is,

$$
\begin{aligned}
& \text { [...] enhancing people's ability to influence their own lives } \\
& \text { and foster a commitment to the development of society. } \\
& \text { Liberal adult education also aims to strengthen and de- } \\
& \text { velop democracy, to broaden the individual's interest in } \\
& \text { the arts, to increase participation in cultural life and to } \\
& \text { encourage experiences and individual creativity (Wikan- } \\
& \text { der, 2010, p. 27) }{ }^{31} \text {. }
\end{aligned}
$$

In this sense that we can locate the Swedish Folk High Schools (folkhögskola), a school organization that has no equivalent in the Brazilian educational system.

Another modality of education existing in Sweden that has no equivalent in the Brazilian educational system is what we can classify as post-secondary education, after the Upper Secondary School. The most varied courses offered by Swedish Folk High Schools (folkhögskola), like the specialized courses (profilkurser) and vocational training courses (yrkesutbildningar), or the complementary education (kompletterande utbildning), or the higher vocational education (yrkeshögskolan), are Swedish examples of post-secondary education, which can either lead the student to higher education (colleges - högskola or universities - 
universitet) or to the labor market (insertion or reinsertion). In Brazil, in turn, what comes closest to a post-secondary education are the socalled sequential courses, but are officially considered higher education courses, not undergraduate courses, but short courses of higher education.

\section{Final Considerations}

Although the performance of Swedish Basic Education in largescale evaluation, specifically PISA, fell between 2000 and 2012 (OECD, 2014), it stabilized in the 2015 edition (OECD, 2016). Beyond the diverse and increasingly divergent views on the real importance and validity of such large-scale assessments, it is much better to be positioned in the first half of a group of 70 countries (more specifically 28th) than to be positioned in the 63rd place, which was the Brazilian position.

Thus, after analyzing the structure and functioning of the Swedish Basic Education and comparing it with the structure and functioning of Brazilian Basic Education, showing some similarities and some major differences, we are forced to counteract Ragin's idea (1987) about the "illusory differences". The differences we find in our analysis do not have any characteristics that allow us to call these differences illusory. On the contrary, these differences are significant, important and real, very real.

Respecting one of the key concepts of the methodology of comparative education, that is, that any analysis that uses this methodology has to take into account a series of crucial factors, such as history, culture, economic conditions, social conditions, among others, we still find considerable differences between the structure and functioning of the Basic Education in Sweden and the structure and functioning of the Brazilian Basic Education.

However, since our main objective was not only to show the differences and possible similarities between these educational systems, but rather to try to identify interesting ideas in the more advanced system (Swedish educational system) that can at least be discussed by the less advanced system (Brazilian educational system), we consider that we reached our goal by highlighting two Swedish educational conceptions different from the ideas in the Brazilian educational area. These two different ideas have behind them different conceptions of how the pedagogical process of teaching and learning for two specific audiences should happen.

The first of these ideas is the existence of the Swedish pre-school class (förskoleklass) with the aim of helping the pupil (actually, first of all, a child of only 6 years) to make as smooth as possible transition from a phase in which the school is basically a place of play (playful), to school as a place of learning of the contents historically accumulated by humanity and transmitted in a more systematized form.

In Brazil, we extended the length of primary education from eight to nine years, and then, immediately, we included 6-year olds in elementary 
The Basic Education in Sweden and Brazil

school. This has only meant that the beginning of the phase in which the school is seen as a place of transmission and learning of formal contents was anticipated in a year in the life of children. This Swedish proposal also shows us that the discussion about the best time to begin formal literacy of the child does not necessarily have to be between the best age, 6 or 7 years, but that there may be an intermediate posture, which is the role (and purpose) of the Swedish pre-school class (förskoleklass).

The other interesting idea that we find in the analysis of the structure and functioning of the Swedish educational system of Basic Education is the same valuation of the conceptions of Inclusive Education and Special Education (for children and young people with learning difficulties and special needs) in the context of Educational policy, whereas in Brazil the concept of Inclusive Education is currently overvalued, making the concept of Special Education for children and young people with special needs and learning difficulties seen as discriminatory and excluding.

We are not discussing which is the best option, but objectively showing that in a country economically, socially and especially culturally developed, the possibility of "peaceful coexistence", in the national public educational policy, between two conceptions of Education for people with special needs, including Inclusive Education and Special Education, is absolutely viable. It also means that the concept of Special Education, understood as an education offered to people with special needs, has specific characteristics (methods, techniques, forms, etc.) and that these people, because they are special, deserve special and specialized attention, it is a conception (pedagogical and social) as valid as the conception of Inclusive Education, therefore, is not necessarily discriminatory.

We are clear that for these two ideas, as for all other differences found, specific research, studies, and discussions are needed, which were not our goal. Our objective was to analyze the structure and functioning of Basic Education in a country considered developed (Sweden) and compare it with the structure and functioning of Brazilian Basic Education, showing differences and possible similarities. The emphasis given in these concluding remarks to two specific ideas serves to prove the relevance of the work with the methodology of Comparative Education, among other reasons, for reinforcing the immense importance of respect for the different ideas and conceptions that should, or at least should, to guide current Brazilian educational thinking.

Received on March 13 $3^{\text {th }}, 2018$ Accepted on June $11^{\text {th }}, 2018$

\section{Notes}

1 The comparison between educational systems is not currently the most discussed topic in Comparative Education. According to Cook, Hite and Epstein (2004, p. 136), the most prominent current theme in the field of Comparative Education is the globalization mark, but we consider this theme very important. 
2 For this paper, we specifically chose the classical authors of Comparative Education, as well as Swedish and Brazilian authors.

3 According to Broadfoot, the comparative education "[...] has always been explicitly or implicitly reformative” (Broadfoot, 2000, p. 366). Another traditional trend in Comparative Education studies is that it takes it as a way of lending or borrowing one educational model to another (Phillips, Ochs, 2003, Steiner-Khamsi, 2004). We emphasize that this article does not follow either in the direction of proposing reforms from the comparison made, nor of borrowing the model of Basic Education of Sweden to implant it in Brazil.

4 As many references are written in Portuguese language, the translations are our own.

5 This author points out, however, that in 1817, Marc-Antonie Jullien had already "[...] outlined the principles, rules and tasks of this new science" (Carvalho, 2014, p. 130). Noah and Eckstein (1969), in describing the five historical steps that Comparative Education has gone through, also point out that the emergence of the earliest studies in Comparative Education dates back to the early nineteenth century, with what they call "traveler's tales" (Noah; Eckstein, 1969).

6 And, according to Halls, the "ideology also has played part" (Halls, 1990, p. 25, original italic).

7 Cowen agues that “[...] there is no single or unified 'Comparative Education' but that there are multiple comparative educations" (Cowen, 2000, p. 333, original quotation marks).

8 Although Kandel's work dates back to the 1930s, in the mid-1960s the Comparative Education, as a field of study, was still struggling for recognition. For King, to be academically and scientifically recognized, Comparative Education needed, among other things, to be understood as a social science (King, 1965, p. 159).

9 According to Altbach, comparative education "[...] is, in any case, not a 'discipline', but rather a multidisciplinary field that looks at educational not necessarily limited to schools or formal educational institutions in a cross-cultural context" (Altbach, 1991, p. 491 original quotation marks).

10 For Halls, it is possible to identify, at least, “[...] half a dozen different 'approches' to comparative education”, (Halls, 1990, p. 31-42, original quotation marks). Kazamias agues for a "[...] return to the historical tradition" in comparative education studies, demonstrating, in a certain way, a decline in the importance of this trend (historical tradition) in the field of comparative education at the beginning of the 21st century (Kazamias, 2001, p. 440).

11 Skollagen is complemented by the Läroplän (curriculum), by the Kursplan (course plans), while specific educational issues are regulated by ordinances (förordningen).

12 Supervision is provided by the Swedish National Agency for Education (Skolverket) and supervision of the quality of Swedish education, both public and private (independent), is done by another agency called Skolinspektionem (Swedish Schools Inspectorate). https://www.skolinspektionem.se, accessed on 28/02/2017.

13 Although not compulsory, Swedish municipalities have the obligation to provide preschool from the year the child is 3 years old, whether the parents are working, studying or even unemployed. General information about the Swedish education also can be found, among other sites, in https://sweden.se/society/educationin-sweden/, accessed on 28/02/2017.

Educação \& Realidade, Porto Alegre, v. 44, n. 1, e81083, 2019. 
The Basic Education in Sweden and Brazil

14 According to Wikander, the number of independent schools, of all education levels, "[...] has increased a lot during the last years" and are present in $60 \%$ of the municipalities in Sweden, especially in the three greater Swedish regions (Wikander, 2010).

15 According to Haddad (2000), when the socialization is also considered a public task, a more comprehensive approach is pursued, which is the case of the Scandinavian countries that "[...] express a shared model of responsibility between family and public power, with early childhood services integrated in a more comprehensive social policy".

16 Also at this elementary school there are independent schools (private). They have to follow the same national curriculum, are supervised by the municipal public authority, but have the freedom to choose the pedagogical method to be used. They may also have a specific religious orientation (Wikander, 2010). According to Wermke (2013) and Carnoy (1998), the voucher system adopted in Sweden from the 1990s onwards has made Swedish education less equal in quality of teaching.

17 The evaluation of knowledge in the Swedish school, by means of concepts, begins only in the sixth year, that is, at the end of the second cycle (mellanstadiet).

18 There are also a little number of international schools to children of foreign nationals whose stay in Sweden is temporary that receive partial government funding (Wikander, 2010).

19 The provision of these programs is the responsibility of the municipalities which, in turn, are obliged to have places for all young people who wish to attend, within the established criteria, Swedish upper secondary education.

20 The central conception of the Folk High Schools (folkhögskola) is recognition and appreciation of the ideological freedom of teaching and learning as living pillars of democracy and safeguarding the basic cultural values of humanity, strongly influenced by the Enlightenment tradition. Thus, the mission of these schools is to defend democracy and fight for the rights of minorities, with discussion and dialogue as pedagogical tools for building citizenship and a more just society. In: http://www.folkhogskola.nu, accessed on 27/03/2017.

21 In Brazil, the evaluation is the responsibility of the Institute of Educational Studies and Research "Anísio Teixeira" (INEP), or of the States, and, the regulation of education is the responsibility of the National Education Council (CNE).

22 The Brazilian day care center is designed for children from 0 to 3 years of age. It is basically based on the idea of "caring for the child" and does not belong to the Brazilian school system.

23 In the context of Brazilian history and culture, the existence of a legal determination is a strong inductive factor, although in the medium and long term.

24 Brazilian educational legislation allows Elementary School to be organized in a variety of ways, but the most commonly used are division by learning cycles or annual grades.

25 This difference between the Swedish and the Brazilian education system exists at both the elementary level (grundskola) and at the upper level (gymnasiet).

26 About indigenous education, see May; Altman (2003).

27 We consider that economic and social factors, are among the main reasons for these two situations (Swedish and Brazilian). 
28 Recently (February 2017), the organization of the Brazilian High School was modified, determining a more professional character for all High Schools, however, such modifications will only be effective as of 2018. Thus, in addition, such modifications did not change the differences between the Swedish and Brazilian educational systems, mentioned in this paragraph.

29 According to Wikander (2010, p. 37), also in Sweden, there is " $[. .$.$] a stronger sepa-$ ration between vocational programmes and theoretically based programmes" (propaedeutic programmes).

30 According to Jarvis, the adult education, the lifelong education and learning is, in the globalized world and learning society, one of the most important fields for studies and research in comparative education (Jarvis, 2000).

31 These liberal adult education organizations can also receive financial funds from the Government to assist in specific educational campaigns or to offer specific training (Wikander, 2010).

\section{References}

ALTBACH, Philip. Trends in Comparative Education. Comparative Education Review, Chicago, n. 35, v. 3, p. 491- 507, 1991.

BROADFOOT, Patricia. Comparative Education for the $21^{\text {st }}$ century: retrospect and prospect. Comparative Education, on-line, n. 36, v. 3, p. 357-371, 2000.

CARNOY, Martin. National Voucher Plans in Chile and in Sweden: did privatization reforms make for better education? Comparative Education Review, Chicago, n. 42, v. 3, p. 309-337, 1998.

CARVALHO, Elma Júlia Gonçalves de. Estudos Comparados em Educação: novos enfoques teórico-metodológicos. Acta Scientiarum, Maringá, n. 36, v. 1, p. 129141, 2014.

COOK, Bradley; HITE, Steven; EPSTEIN, Erwin. Discerning Trends, Contours and Boundaries in Comparative Education: survey of comparativists and their literature. Comparative Education Review, Chicago, n. 48, p. 123-149, 1998.

COWEN, Robert. Comparing Futures or Comparing Pasts? Comparative Education, on-line, n. 36, v. 3, p. 333-342, 2000.

FRANCO, Maria Aparecida Ciavatta. Estudos Comparados em Educação na América Latina: uma discussão teórico-metodológica a partir da questão do outro. In: PUIGGRÓS, Adriana; BERTUSSI, Guadelupe Teresinha; FRANCO, Maria Aparecida Ciavatta (Org.). Estudos Comparados e Educação na América Latina. São Paulo: Livros do Tatu/Cortez, 1992.

HADDAD, Lenira. The Ecology of Day Care: building a model for an integrated system of care and education. European Conference on Quality in Early Childhood Education, London, England, n. 1, 2000.

HALLS, Wilfred Douglas. Trends and Issues in Comparative Education. In: HALLS, Wilfred Douglas (Org.). Comparative Education: contemporary issues and trends. London: Jessica Kingsley Publishers, 1990.

JARVIS, Peter. Globalisation, the Learning Society and Comparative Education. Comparative Education, on-line, n. 36, v. 3, p. 343-355, 2000.

KANDEL, Isaac Leon. Studies in Comparative Education. Boston: Houghton Mifflin Company, 1933. 
The Basic Education in Sweden and Brazil

KAZAMIAS, Andreas. Re-inventing the Historical in Comparative Education: reflections on a protean episteme by a contemporary player. Comparative Education, on-line, n. 37, v. 4, p. 439-449, 2001.

KING, Edmund. The Purpose of Comparative Education. Comparative Education, on-line, n. 3, v. 1, p. 147-159, 1965.

LIMA, Licínio Carlos Viana da Silva; AFONSO, Almerindo Janela Gonçalves. Democratização, Modernização e Neoliberalismo. Porto: Edições Afrontamento, 2002.

MAKUWIRA, Jonathan; NINNES, Peter. Post-Development Theory and Comparative Education. In: NINNES, Peter; MEHTA, Sonia (Org.). Re-Imagining Comparative Education: postfoundational ideas and applications for critical times. New York; London: RoutledgeFalmer, 2004.

MAY, Stephen; ALTMAN, Sheila. Indigenous Education: addressing current issues and developments. Comparative Education, on-line, n. 39, v. 2, p. 139-145, 2003.

NOAH, Harold; ECKSTEIN, Max. Towards a Science of Comparative Education. London: The Macmillan Company, 1969.

OECD. Organisation for Economic Co-operation and Development. Country Note: education at a glance 2014 - Sweden. Paris: OEDC, 2014. Disponível em: <http://www.oecd.org/edu/Sweden-EAG2014-Country-Note.pdf>. Acesso em: 30 mar. 2017.

OECD. Organisation for Economic Co-operation and Development. PISA 2015 Results in Focus. Paris: OECD, 2016. Disponível em: <http://www.oecd.org/pisa/ pisa-2015-results-in-focus.pdf $>$. Acesso em: 21 abr. 2017.

PHILLIPS, David; OCHS, Kimberly. Processes of Policy Borrowing in Education: some explanatory and analytical devices. Comparative Education, on-line, n. 39, v. 4, p. 451-461, 2003.

RAGIN, Charles. The Comparative Method: moving beyond qualitative and quantitative strategies. Berkeley: University of California Press, 1987.

STEINER-KHAMSI, Gita (Org.). The Global Politics of Educational Borrowing and Lending. New York: Teachers College Press, 2004.

WERMKE, Wieland. Development and Autonomy: conceptualizing teachers continuing professional development in different national contexts. 2013. Tese (Doutorado em Educação) - Universidade de Estocolmo, Estocolmo, 2013.

WIKANDER, Lennart. The Educational System in Sweden: from a uniform towards a dual model. Pedagogisk Forskning I Uppsala, Upsália, n. 158, p. 5-42, 2010.

Carlos da Fonseca Brandão completed his Postdoctoral study of Education at Universidad Rovira I Vigili and Universidad Autónoma de Barcelona. He has a doctorate in Education and is a Professor at Universidade Estadual Paulista (UNESP).

ORCID: http://orcid.org/0000-0003-2254-0692

E-mail: cbrandao@assis.unesp.br

This is an open-access article distributed under the terms of the Creative Commons Attribution License 4.0 International. Available at: <http://creativecommons.org/licenses/by/4.0>. 